\title{
Effects of gadolinium and tin to the production of oxidative enzymes and the growth of five basidiomycetous fungi
}

Kähkönen, Mika A.

2017

Kähkönen , M A , Miettinen , O , Kinnunen , A \& Hatakka , A 2017 , ' Effects of gadolinium and tin to the production of oxidative enzymes and the growth of five basidiomycetous fungi ' , Expert opinion on environmental biology , vol. 06 , no. 01 , 1000139 , pp. 1-4 . https://doi.org/10.4172/2325-9655.1

http://hdl.handle.net/10138/196941

https://doi.org/10.4172/2325-9655.1000139

publishedVersion

Downloaded from Helda, University of Helsinki institutional repository.

This is an electronic reprint of the original article.

This reprint may differ from the original in pagination and typographic detail.

Please cite the original version. 


\section{Expert Opinion on Environmental Biology}

\section{Effects of Gadolinium and Tin to the Production of Oxidative Enzymes and the Growth of Five Basidiomycetous Fungi}

\section{Mika A Kähkönen ${ }^{1 *}$, Otto Miettinen ${ }^{2}$, Anu Kinnunen ${ }^{1}$ and Annele Hatakka ${ }^{1}$}

\begin{abstract}
Effects of gadolinium (Gd) and tin ( $\mathrm{Sn})$ on the growth and production of oxidative enzymes with five basidiomycetous fung were tested. For this study we have selected well-known white-rot fungi Obba rivulosa and Kuehneromyces mutabilis, in addition to this we have tested three new isolates, the white-rot fungus Phlebia subochracea, the litter-degrading fungus Gymnopus dryophilus and the brown-rot fungus Heliocybe sulcata. This approach allowed us to find possible new sources for oxidative enzymes, such as laccases and versatile peroxidases (VPs). All five tested fungi grew in the presence of $\mathrm{Gd}(0-200 \mathrm{mg} / \mathrm{l})$ or $\mathrm{Sn}(0-200 \mathrm{mg} / \mathrm{l})$ on ABTS (2,2'-azino-bis(3-ethylbenzthiazoline-6-sulfonic acid) containing plates. The growth rate of $H$. sulcata was tolerant to $\mathrm{Gd}$ and $\mathrm{Sn}(0-$ $200 \mathrm{mg} / \mathrm{ll}$. The growth rates of $P$. subochracea and G. dryophilus were sensitive to $\mathrm{Gd}(5-200 \mathrm{mg} / \mathrm{l})$ and $\mathrm{Sn}(5-200 \mathrm{mg} / \mathrm{l})$. O. rivulosa, K. mutabilis, P. subochracea and G. dryophilus formed colour zones on the ABTS plates indicating that these fungi produced oxidative enzymes, most probably laccases. The brown-rot fungus $H$. sulcata did not form colour zone on the ABTS plate indicating that this fungus did not produce laccase. The production of laccase with $G$. dryophilus and $K$. mutabilis was tolerant to $\mathrm{Gd}(0-200 \mathrm{mg} / \mathrm{l})$ and $\mathrm{Sn}$ (0-200 $\mathrm{mg} / \mathrm{l})$. The production of laccase with $P$. subochracea was sensitive to $\mathrm{Gd}(5-200 \mathrm{mg} / \mathrm{l})$ and $\mathrm{Sn}(5-200 \mathrm{mg} / \mathrm{l})$. P. subochracea decolorized the dye Reactive Black 5 without or with $\mathrm{Gd}$ and Sn (0$200 \mathrm{mg} / \mathrm{l})$ indicating the production of VP. O. rivulosa, K. mutabilis, $G$. dryophilus and $H$. sulcata did not produce VP. The production of VP by $P$. subochracea was sensitive to $200 \mathrm{mg} / \mathrm{l} \mathrm{Gd}$ and $\mathrm{Sn}$.
\end{abstract}

\section{Keywords}

Gadolinium; Tin; Basidiomycetous fungi; Oxidative enzyme; Laccase; Versatile peroxidase

\section{Introduction}

Harmful xenobiotics are released from various sources to the soil and water. Contaminated soil and water need new technologies so that these are possible to remediate to clean and safe. All whiterot fungi are able to produce oxidative lignin modifying enzymes, such as laccases and versatile peroxidases (VPs) [1-3]. These two

*Corresponding author: Mika Kähkönen, PhD., docent, University of Helsinki, Department of Food and Environmental Sciences, Microbiology and Biotechnology Division, Biocenter, P.O. Box 56, 00014 University of Helsinki, Finland, Tel: +358-9-19159332; Fax: +358-(0)9-19159301; E-mail: mika kahkonen@helsinki.fi

Received: December 05, 2016 Accepted: December 30, 2016 Published: January 04, 2017 oxidative enzymes are suitable for remediation of harmful xenobiotic compounds, particularly aromatic structure containing compounds in contaminated environment and recycling of carbon from natural compounds [3-6]. VP typically catalyzes oxidation reaction, where an aromatic structure containing dye compound, Reactive Black 5, in the presence of $\mathrm{H}_{2} \mathrm{O}_{2}$ is transformed to the oxidized (bleached) form of Reactive Black 5 and water [7,8]. VP has properties of both manganese peroxidase and lignin peroxidases and has non-specific substrate specificity [9-11]. VPs are biotechnologically interesting since they do not need a mediator for the oxidation of substrate $[2,10]$. Laccases have broad substrate specificity and they are useful in many biotechnological applications [2]. Basidiomycetous fungi are able to decolorize several synthetic dyes [2]. Brown-rot fungi produce hydrolytic enzymes, which degrade cellulose and hemicellulose, but usually do not produce laccase or ligninolytic peroxidases [2]. Contaminated areas are often polluted with organic xenobiotic compounds and metals. Rare earth elements include the lanthanide gadolinium (Gd). The mean abundance of Gd is $5.4(2.2-7.9) \mu \mathrm{g} \mathrm{g}^{-1}$ $\mathrm{dw}$ at 30 sites in A-horizon in Swedish forest soil [13]. Gd containing compounds have been used as paramagnetic contrast agents for people who need magnetic resonance Imaging $[14,15]$. Gd has been found in the waste water [14,15] and in contaminated soil [2]. Tin $(\mathrm{Sn})$ is present in waste water effluents and contaminated soils [17] and sediments [18]. $\mathrm{Sn}$ is a post-transition metal, which belongs to group 14 in the periodic table. The white rot fungi Obba rivulosa (=Physisporinus rivulosus, [19]) and Kuehneromyces mutabilis [20,21] were selected for this study. New isolates the white-rot fungus Phlebia subochracea, the litter-degrading fungus Gymnopus dryophilus and the brown-rot fungus Heliocybe sulcata were selected for this study to find possible new sources of oxidative enzymes, namely laccases and versatile peroxidases. Only a little is known about impacts of gadolinium and tin on any basidiomycetous fungi. The aim this study of was to find out effects of gadolinium (Gd) and tin (Sn) to the growth rate and production of extracellular oxidative laccase enzyme of basidiomycetous fungi.

\section{Materials and Methods}

For this study five functionally different basidiomycetous fungi were selected from the Fungal Biotechnology Culture Collection (FBCC) at the University of Helsinki, Department of Food and Environmental Sciences, Microbiology and Biotechnology Division. The fungi were Kuehneromyces mutabilis (Agaricales, FBCC 508) and Obba rivulosa (= Ceriporiopsis rivulosa, Physisporinus rivulosus, Polyporales, FBCC 939). The new isolates of fungi, which were studied first time in the present study, were Phlebia subochracea (Polyporales), OM 19353, FBCC 2376, Gymnopus dryophilus (Agaricales), OM 19240, FBCC 2376 and Heliocybe sulcata (Gloeophyllales), OMC 1185 , FBCC 2375. The draft genome of $H$. sulcata has been produced by Joint Genome Institute, CA, USA.

\section{Indicator plate tests}

Effects of selected metals on the production of extracellular oxidative enzymes and the growth of six basidiomycetous fungi were tested with gadolinium $\left(0,5,50,200 \mathrm{mg} \mathrm{Gd} \mathrm{kg}^{-1}\right)$ and tin $(0,5$,

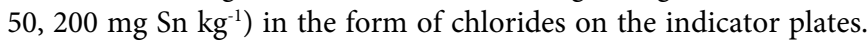
The test chemicals were $\mathrm{GdCl}_{3} \cdot 6 \mathrm{H}_{2} \mathrm{O}$ (Sigma-Aldrich, U.S.A.) and 
$\mathrm{SnCl}_{4} \cdot 5 \mathrm{H}_{2} \mathrm{O}$ (Sigma-Aldrich, U.S.A). The basic test medium had 10 g glucose, $2 \mathrm{~g} \mathrm{KH}_{2} \mathrm{PO}_{4}$, 0,5 g $\mathrm{MgSO}_{4} 7 \mathrm{H}_{2} \mathrm{O}, 0,1 \mathrm{~g} \mathrm{CaCl}_{2}, 0,5 \mathrm{~g} \mathrm{NH}_{4}^{-}$ tartrate, 2.2 dimethylsuccinate, $0,1 \mathrm{~g}$ yeast extract and $25 \mathrm{~g}$ agar per litre. The $\mathrm{pH}$ was adjusted to 5.0. The medium for indicator plates was supplemented with $250 \mathrm{mg} \mathrm{kg}^{-1}$ ABTS (2,2'-azino-bis(3ethylbenzthiazoline-6-sulfonic acid, Sigma-Aldrich, U.S.A.) or 250 mg kg-1 RB5 (Reactive Black 5, Sigma-Aldrich, U.S.A.). All indicator plates were done as triplicate. For inoculum, a fungus-containing malt $(2 \% \mathrm{w} / \mathrm{v})$ agar plug, which had a $4 \mathrm{~mm}$ diameter, was added to the center of the indicator plate. The plates were incubated at $25.0^{\circ} \mathrm{C}$. The formed green colour in the ABTS containing plate indicated the production of oxidative enzyme, most probably laccase. The growth and the colour changes were measured at four positions across the plate at $90^{\circ}$ angles, and averages of these four measurements per plate were calculated.

\section{Statistical tests}

ANOVA was performed to test statistical difference between the growth rate and the formation of colour zone with certain fungi in the presence of added Sn or Gd compared to those without added metal. Tukey test was performed as a post-hoc test. Statistical tests were done with SPSS Statistics software (IBM).

\section{Results}

Figure 1A displays the growth of five basidiomycetous fungi with and without tin (Sn). All five fungi grew in the presence of Sn. The growth rate of fungi without added metal decreased in the following order, which was O. rivulosa, $H$. sulcata, P. subochracea, K. mutabilis and G. dryophilus The growth rate of $K$. mutabilis and $O$. rivulosa remained stable with $5-50 \mathrm{mg} / \mathrm{l}$ and decreased with $200 \mathrm{mg} \mathrm{Sn} / \mathrm{l}$ compared to the control indicating that $K$. mutabilis and $O$. rivulosa were tolerant to $\mathrm{Sn}$ in the lower concentrations. The growth rate of $P$. subochracea and G. dryophilus decreased with $5-200 \mathrm{mg} / \mathrm{l}$ indicating that $P$. subochracea and G. dryophilus were sensitive to $\mathrm{Sn}$. The growth rate of $H$. sulcata remained similar or even increased in the presence of $\mathrm{Sn}(5-200 \mathrm{mg} / \mathrm{l})$ compared to the control indicating that $H$. sulcata also benefitted from the Sn.

Figure 1B displays the growth of five basidiomycetous fungi in the presence of gadolinium (Gd). All five fungi grew in the presence of Gd. The growth rate of $K$. mutabilis and O. rivulosa remained stable with $5-50 \mathrm{mg} \mathrm{Gd} / 1$ and decreased in the presence of $200 \mathrm{mg} \mathrm{Gd} / \mathrm{l}$ indicating that these fungi were sensitive to higher $\mathrm{Gd}$ concentrations. The growth of $H$. sulcata remained similar or even increased in the presence of 5-200 mg Gd/l indicating that $H$. sulcata was tolerant to Gd. The growth of $P$. subochracea and G. dryophilus decreased in the presence of 5-200 mg Gd/l indicating that P. subochracea and $G$. dryophilus were sensitive to $\mathrm{Gd}$.

Figure 2A displays the formation of colour zone in ABTS containing plates in the presence of tin (Sn). K. mutabilis, O. rivulosa, P. subochracea and G. dryophilus formed colour zone in the ABTS containing plates in the presence of $\mathrm{Sn}$ indicating production of oxidative enzyme, most probably laccase. $H$. sulcata did not form colour zone indicating that $H$. sulcata does not produce any oxidative enzymes. The formation rate of colour zone with G. dryophilus increased with $5-200 \mathrm{mg} \mathrm{Sn} / 1$ indicating that the production of laccase enzyme with $G$. dryophilus benefitted from Sn. The formation rate of colour zone with $P$. subochracea decreased in the presence of 5-200 mg Sn/l indicating that Sn was harmful to P. subochracea. The formation rate of colour zone remained stable or even increased with $K$. mutabilis in the presence of 5-200 $\mathrm{mg} \mathrm{Sn} / \mathrm{l}$ indicating that $K$. mutabilis was tolerant to $\mathrm{Sn}$. The formation rate of colour zone with O. rivulosa in the presence of $200 \mathrm{mg} \mathrm{Sn} / \mathrm{l}$ decreased indicating that O. rivulosa was sensitive to $\mathrm{Sn}$.

Figure $2 \mathrm{~B}$ displays the formation of colour zone in ABTS containing plates in the presence of gadolinium $(\mathrm{Gd})$. The formation of colour zone in ABTS plate indicates the production of oxidative laccase enzyme. K. mutabilis, O. rivulosa, P. subochracea, and G. dryophilus formed colour zone in the ABTS containing plates indicating production of laccase type activity. The production rate of colour zone decreased with $P$. subochracea in the presence of $5-200 \mathrm{mg} \mathrm{Gd} / 1$ indicating that $P$. subochracea is sensitive to Gd. The production rate of colour zone even increased with G. dryophilus in the presence of 5-200 mg Gd/l indicating that G. dryophilus even benefitted from Gd. The production rate of colour zone with $200 \mathrm{mg}$ $\mathrm{Gd} / \mathrm{l}$ remained stable with $K$. mutabilis and O. rivulosa indicating that these fungi are tolerant to $\mathrm{Gd}$.

The decolorization rate of Reactive Black 5 (RB5) in the presence of tin (Sn) or gadolinium (Gd) was studied. P. subochracea decolorized RB5 in the presence of $\mathrm{Sn}$ or Gd or without added metal indicating that this fungus produced versatile peroxidase (VP) activity. The other four fungi K. mutabilis, O. rivulosa, G. dryophilus and $H$. sulcata, did not decolorize RB5 indicating that these fungi did not produce VP. The production rate of VP with $P$. subochracea remained similar with 5-50 mg/l Sn and Gd and decreased $27 \%$ with $200 \mathrm{mg}$ $\mathrm{Sn} / \mathrm{l}$ and $9 \%$ with $200 \mathrm{mg} \mathrm{Gd} / \mathrm{l}$ indicating that the production rate by $P$. subochracea was sensitive to higher Sn and Gd concentrations.

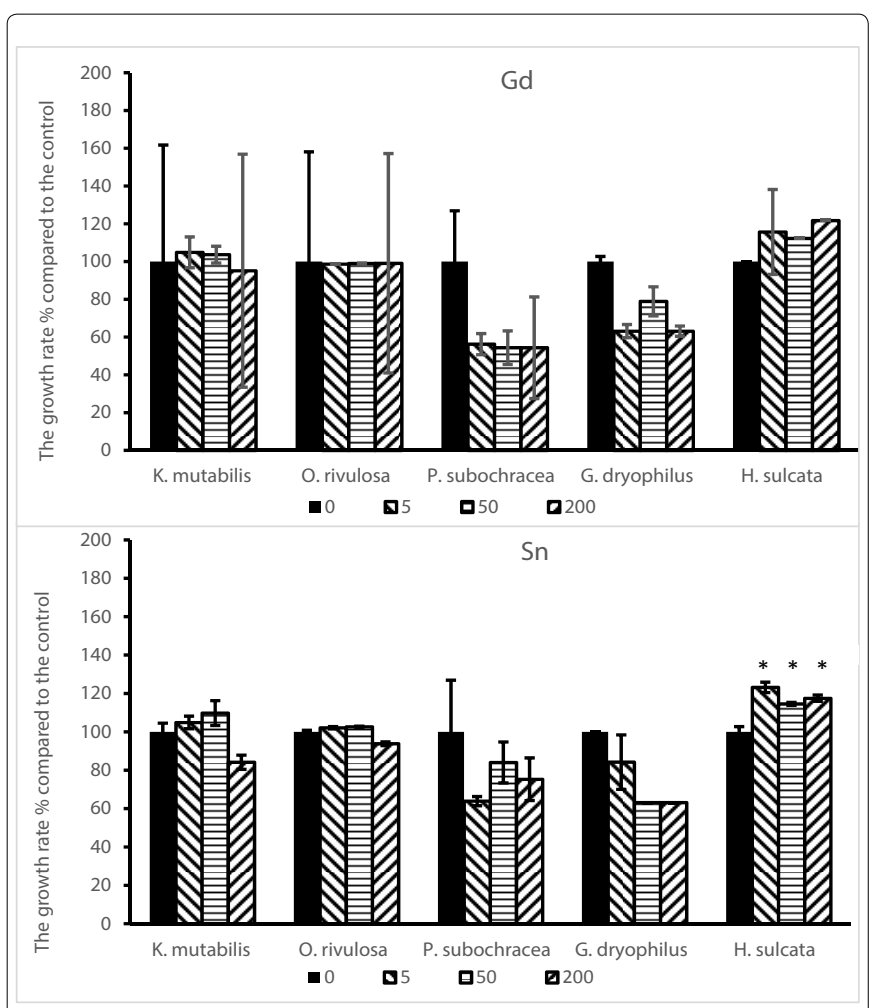

Figure 1: The growth rate of five basidiomycetous fungi with tin (Sn) or gadolinium (Gd) compared to those without added metal. A. Lower panel: with Sn. B. Upper panel: with Gd. Asterisks $\left(^{*}\right)$ indicates statistically significant differences $(p<0.05)$ between with and without added metal (control). Bars represent standard error of mean $(n=3)$. 


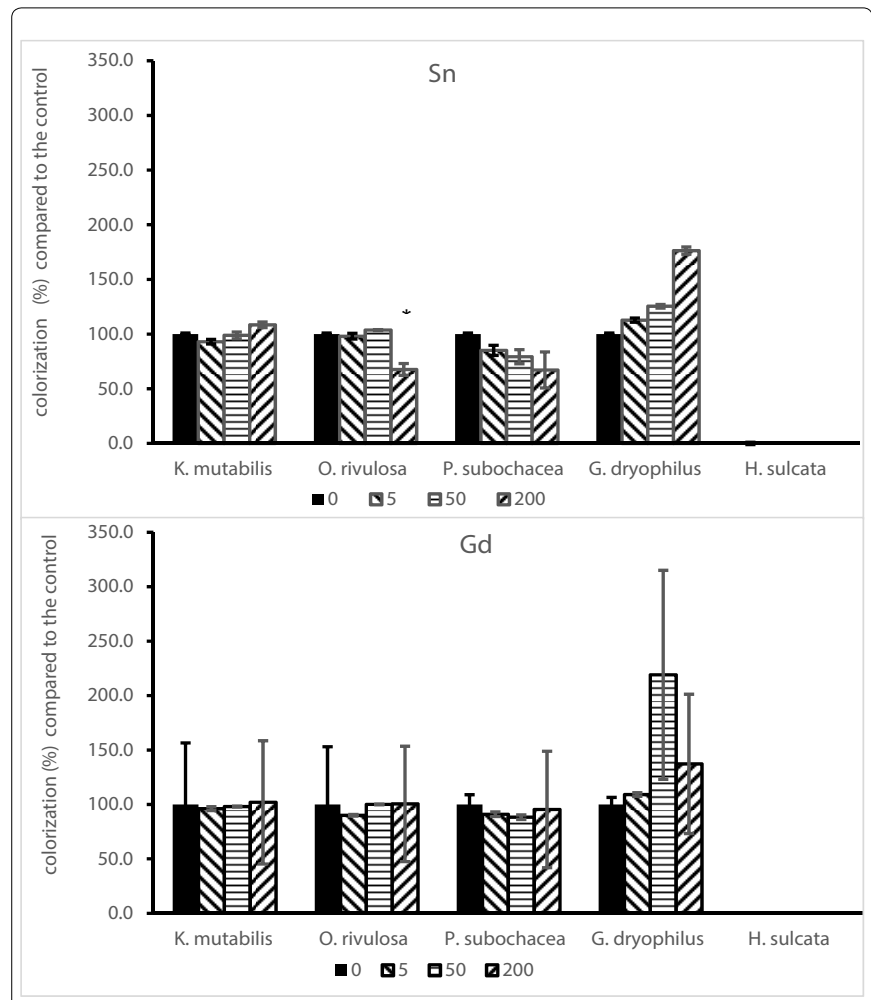

Figure 2: The colour formation rate of five basidiomycetous fungi with tin $(\mathrm{Sn})$ or gadolinium $(\mathrm{Gd})$ on ABTS plate compared to those without added metal. A. Upper panel: with Sn. B. Lower panel: with Gd. Asterisks (*) indicates statistically significant differences $(p<0.05)$ between with and without added metal (control). Bars represent standard error of mean $(n=3)$.

\section{Discussion}

All five tested fungi grew in the presence of Sn and Gd. Our study is the first to test impacts of $\mathrm{Sn}$ and $\mathrm{Gd}$ on the growth rate of the brown-rot fungus $H$. sulcata, and it was found to be tolerant to $\mathrm{Sn}$ and Gd. The growth rates of the white-rot fungi K. mutabilis and $P$. rivulosus were tolerant to $\mathrm{Sn}$ and $\mathrm{Gd}$ with $5-50 \mathrm{mg} / \mathrm{l}$ and sensitive in the higher $\mathrm{Sn}$ and $\mathrm{Gd}$ concentrations $(200 \mathrm{mg} / \mathrm{l})$ indicating that these fungi are suitable for bioremediation of the low level Sn or Gd contaminated soil. It was earlier reported that $K$. mutabilis grows less than $30 \%$ in the presence of $\mathrm{ZnO}$ or $\mathrm{Cu}_{2} \mathrm{O}$ at concentration of $1 \mathrm{~g} / \mathrm{l}$ in the basic agar medium compared to those without added metal $[21,22]$. Thus high $\mathrm{ZnO}$ or $\mathrm{Cu}_{2} \mathrm{O}$ concentrations seem to inhibit the growth of K. mutabilis, as was seen in the present study with $200 \mathrm{mg} / \mathrm{l}$ Sn and Gd concentrations. Impacts of different metals greatly vary on the growth rate of $P$. rivulosus. The growth of $P$. rivulosus was vulnerable in the presence of Cd (5-10 $\left.\mathrm{mg} \mathrm{kg}^{-1}\right)$, Co $\left(20 \mathrm{mg} \mathrm{kg}^{-1}\right), \mathrm{Cr}$ (20-100 $\left.\mathrm{mg} \mathrm{kg}^{-1}\right), \mathrm{Li}\left(20-100 \mathrm{mg} \mathrm{kg}^{-1}\right)$ [10] and of $\mathrm{Al}\left(50-200 \mathrm{mg} \mathrm{kg}^{-1}\right)$, Mo (10-50 $\left.\mathrm{mg} \mathrm{kg}^{-1}\right)$ and V $\left(20 \mathrm{mg} \mathrm{kg}^{-1}\right)$ [23]. The growth of $P$. rivulosus was tolerant to $\mathrm{Zr}\left(0-50 \mathrm{mg} \mathrm{kg}^{-1}\right)$ and $\mathrm{Ga}\left(20-100 \mathrm{mg} \mathrm{kg}^{-1}\right)$ [23]. Our study is the first test on the growth rates of the white-rot fungus $P$. subochracea and the litter-degrading fungus $G$. dryophilus along with their sensitivity to Sn and Gd. The growth rates of these two fungi, P. subochracea and G. dryophilus, were most sensitive to $\mathrm{Sn}$ and Gd, indicating that these fungi are not suitable for bioremediation in the contaminated soil.

Four of the five tested fungi, K. mutabilis, O. rivulosa, $P$. subochracea and G. dryophilus, showed formation of the colour zone in the ABTS containing plates indicating the production of oxidative enzymes, namely laccases and peroxidases. The production of laccase has been reported by P. rivulosus [24], K. mutabilis [25] and other isolate of G. dryophilus (= Collybia dryophila, K209) and tested in the present study [26]. The white-rot fungus $P$. rivulosus showed colour zone on ABTS plates [12] with $\mathrm{Al}, \mathrm{W}, \mathrm{Ga}, \mathrm{Zr}, \mathrm{Mo}$ and $\mathrm{V}$ and without metals [23] as was observed also in the present study. P. rivulosus was sensitive to $\mathrm{Al}, \mathrm{Mo}, \mathrm{V}, \mathrm{W}$ and $\mathrm{Zr}$ and tolerant to $\mathrm{Ga}$ [23]. Ten of eighteen tested Phlebia species including Phlebia subochracea HHB8494 were able to degrade over 50\% organochloride pesticide heptachlor [27]. Our study shows formation of the colour zone in the ABTS containing plates indicating production of laccase type activity by P. subochracea OM19353 and G. dryophilus OM19240. H. sulcata did not form colour zone in ABTS plates indicating that it does not produce oxidative enzymes such as laccases and peroxidases, which indicates that $H$. sulcata is a typical brown-rot fungus. The brown-rot fungi do not usually produce laccases or lignin modifying peroxidases [2], although there are some exceptions. Along with this gene encoding laccases have been found in the whole genomes of some brown-rot fungi [28].

Reactive Black 5 (RB5) is a specific substrate to test the activity of versatile peroxidase (VP), which oxidizes directly RB5 without mediators, and it can be seen as decolorization of RB5. This dye has been used to screen VP activity in a number of lignin degrading fungi [29]. Lignin peroxidase needs a redox mediator to oxidize this compound [2]. Our study is the first study which shows that $P$. subochracea decolorized RB5 in the presence of Sn or Gd or without added metal indicating that this fungus produces VP activity. The other two white-rot fungi $K$. mutabilis and O. rivulosa did not produce VP activity in the present study. We also showed that G. dryophilus and $H$. sulcata did not decolorize RB5 indicating that these fungi did not produce VP activity.

\section{Conclusions}

The three new isolates, the white-rot fungus $P$. subochracea, the litter-degrading fungus G. dryophilus and the brown-rot fungus $H$. sulcata as well as the earlier isolated and much studied white-rot fungi $P$. rivulosus and $K$. mutabilis grew in the presence of Sn (0-200 $\mathrm{mg} / \mathrm{l})$ and $\mathrm{Gd}(0-200 \mathrm{mg} / \mathrm{l})$. The formation rate of colour zones with $P$. rivulosus, K. mutabilis, P. subochracea and G. dryophilus on the ABTS plates indicated that these four fungi produce laccase type oxidative enzyme. No formation of colour zone with the brown-rot fungus $H$. sulcata was seen on the ABTS plates indicating that $H$. sulcata did not produce any oxidative enzymes, which was also expected as it is a brown-rot fungus.

\section{Acknowledgments}

We thank the Maj and Tor Nessling Foundation for financial support of the study. We also thank lab technician traineers Larisa Doty, Anni-Marjukka Julin and Tomi Stockmakare for their technical support.

\section{References}

1. Baldrian $P(2006)$ Fungal laccases - occurrence and properties. FEMS Microbiol Rev 30: 215-242.

2. Hatakka A, Hammel KE (2010) Fungal Biodegradation of Lignocelluloses Industrial Applications (10th edn.), Springer-Verlag, Berlin.

3. Martínez AT, Speranza M, Ruiz-Dueñas FJ, Ferreira P, Camarero S, et al. (2005) Biodegradation of lignocellulosics: microbial, chemical, and enzymatic aspects of the fungal attack of lignin. Res Rev Int Microbiol 8:195-204.

4. Hatakka A (1994) Lignin-modifying enzymes from selected white-rot fungi: Production and role in lignin degradation. FEMS Microbiol Rev 13: 125-135. 
Citation: Kähkönen MA, Miettinen O, Kinnunen A, Hatakka A (2017) Effects of Gadolinium and Tin to the Production of Oxidative Enzymes and the Growth of Five Basidiomycetous Fungi. Expert Opin Environ Biol 6:1.

5. Davila-Vazqueza G, Tinocoa R, Pickard MA, Vazquez-Duhalta R (2005) Transformation of halogenated pesticides by versatile peroxidase from Bjerkandera adusta. Enzyme Microb. Technol 36: 223-231.

6. Viswanath B, Rajesh B, Janardhan A, Kumar AP, Narasimha G (2014) Fungal laccases and their applications in bioremediation. Enzyme Res 2014: 163242.

7. Ruiz-Dueñas FJ, Martínez MJ, Martínez AT (1999) Molecular characterization of a novel peroxidase isolated from the ligninolytic fungus Pleurotus eryngii. Mol Microbiol 31: 223-235.

8. Knop D, Levinson D, Makovitzki A, Agami A, Lerer E, et al (2016) Limits of Versatility of Versatile Peroxidase. Appl Environ Microbiol 82: 4070-4080.

9. Caramelo L, Martinez MJ, Martinez AT (1999) A search for ligninolytic peroxidases in the fungus Pleurotus eryngii involving a-Keto- $\gamma$ thiomethylbutyric acid and lignin model dimers. Appl Environ Microbiol 65 916-922.

10. Moreira PR, Almeida-Vara E, Malcata FX, Duarte JC (2007) Lignin transformation by a versatile peroxidase from a novel Bjerkandera sp. strain. Int Bioterior Biodegradation 59: 234-238.

11. Ruiz-Dueñas FJ, Camarero S, Pérez-Boada M, Martínez MJ, Martínez AT (2001) A new versatile peroxidase from Pleurotus. Biochem Soc Trans 29: 116-122.

12. Hartikainen ES, Miettinen O, Hatakka A, Kahkonen MA (2016). Decolorization of Six Synthetic Dyes by Fungi. American Journal of Environmental Sciences 12: $77-85$

13. Tyler G (2004) Rare earth elements in soil and plant systems-A review. Plant Soil 267: 191-206.

14. Lawrence MG, Ort C, Keller J (2009) Detection of anthropogenic gadolinium in treated wastewater in South East Queensland, Australia. Water Res 43 3534-3540.

15. Rabiet M, Brissaud F, Seidel JL, Pistre S, Elbaz-Poulichet F (2009) Positive gadolinium anomalies in wastewater treatment plant effluents and aquatic environment in the Hérault watershed (South France). Chemosphere 75 : 1057-1064.

16. Brioschi L, Steinmann M, Lucot E., Pierret MC, Stille $P$, et al. (1997) Trivalent soils and metal $(\mathrm{Cr}, \mathrm{Y}, \mathrm{Rh}, \mathrm{La}, \mathrm{Pr}, \mathrm{Gd})$ sorption in two acid its consequences for bioremediation. Eur J Soil Biol 48: 697-702.

17. Hirner V, Gruter UM, Kresimon J (2000) Metal (loid) organic compounds in contaminated soil. Fresenius J Anal Chem 368: 263-267.

18. Landmeyer AE, Tanner TL, Watt BE (2004) Biotransformation of tributyltin to tin in freshwater river-bed sediments contaminated by an organotin release. Environ Sci Technol 38: 4106-4112.

19. Hakala TK, Maijala P, Konn J, Hatakka A (2004) Evaluation of novel woodrotting polypores and corticioid fungi for the decay and biopulping of Norway spruce (Picea abies) wood. Enzyme Microb Tech 34: 255-263.

20. Gramss G, Ziegenhagen D, Sorge S (1999) Degradation of Soil Humic Extract by Wood- and Soil-Associated Fungi, Bacteria, and Commercial Enzymes. Microb Ecol 37: 140-151.

21. Jarosz-Wilkolazka A, Graz M (2006) Organic acids production by white rot Basidiomycetes in the presence of metallic oxides. Can J Microbiol 52: 779-785.

22. Hartikainen ES, Hatakka A, Kahkonen MA (2013) Impact of Cadmium, Chromium, Cobalt, Lithium and Manganese to the Growth of Fungi and Production of Enzymes. Expert Opin Environ Biol 2:3.

23. Kluczek-Turpeinen B, Holm J Hatakka A, Kahkonen MA (2014) Impacts of Aluminium, Molybdenum, Vanadium, Zirconium, Tungsten and Gallium on the Growth and Enzyme Production of Ascomycetous and Basidiomycetous Fungi. Annals Environ Sci 8.

24. Hilden KS, Hakala TK, Maijala P, Lundell T, Hatakka A (2007) Novel thermotolerant laccases produced by the white-rot fungus Physisporinus rivulosus. Appl Microbiol Biotechnol 77: 301-309.

25. Cho NS, Park JM, Choi TH, Matuszewska A, Jaszek M, et al. (1999) The effects of wood rotting fungi and laccase on destaining of dyes and KP bleaching effluent. J Korean Wood Sci Technol 27: 72-79.

26. Steffen KT, Hatakka A, Hofrichter M (2002) Degradation of Humic Acids by the Litter-Decomposing Basidiomycete Collybia dryophila. Appl Environ Microbiol 68: 3442-3448.
27. Xiao P, Mori T, Kamei I, Kondo R (2011) Metabolism of organochlorine pesticide heptachlor and its metabolite heptachlor epoxide by white rot fungi, belonging to genus Phlebia. FEMS Microbiol Lett 314: 140-146.

28. Floudas D, Binder M, Riley R, Barry K, Blanchette RA, et al. (2012) The Paleozoic origin of enzymatic lignin decomposition reconstructed from31 fungal genomes. Sci 336: 1715-1719.

29. Kinnunen A, Maijala $P$, Jarvinen $P$, Hatakka A (2016) Improved efficiency in screening for lignin-modifying peroxidases and laccases of basidiomycetes. Curr Biotechnol 5.

\section{Author Affiliations}

${ }^{1}$ Department of Food and Environmental Sciences, Division of Microbiology and Biotechnology, P.O. Box 56, Biocenter 1, Fl 00014 University of Helsinki, Finland

${ }^{2}$ Botanical Museum, Finnish Museum of Natural History, P.O. Box 7, Fl 00014 University of Helsinki, Finland

Submit your next manuscript and get advantages of SciTechnol submissions

* 80 Journals

* 21 Day rapid review process

* 3000 Editorial team

* 5 Million readers

* More than 5000 facebook"

* Quality and quick review processing through Editorial Manager System

Submit your next manuscript at $\bullet$ www.scitechnol.com/submission 